NBER WORKING PAPER SERIES

\title{
SAVING YOUR HOME IN CHAPTER 13 BANKRUPTCY
}

\author{
Michelle J. White \\ Ning Zhu \\ Working Paper 14179 \\ http://www.nber.org/papers/w14179 \\ NATIONAL BUREAU OF ECONOMIC RESEARCH \\ 1050 Massachusetts Avenue \\ Cambridge, MA 02138 \\ July 2008
}

We are grateful to an anonymous referee and to Richard Hynes for very helpful comments. We also benefitted from comments by participants at presentations at the University of Virginia Law School, NYU Law School, and the Richmond Federal Reserve Bank. The views expressed herein are those of the author(s) and do not necessarily reflect the views of the National Bureau of Economic Research.

NBER working papers are circulated for discussion and comment purposes. They have not been peerreviewed or been subject to the review by the NBER Board of Directors that accompanies official NBER publications.

(C) 2008 by Michelle J. White and Ning Zhu. All rights reserved. Short sections of text, not to exceed two paragraphs, may be quoted without explicit permission provided that full credit, including (C notice, is given to the source. 
Saving Your Home in Chapter 13 Bankruptcy

Michelle J. White and Ning Zhu

NBER Working Paper No. 14179

July 2008, Revised April 2009

JEL No. G33,G38,K35,R31

\begin{abstract}
This paper examines how filing for bankruptcy under Chapter 13 helps financially distressed debtors save their homes. We develop a model of debtors' decisions to default on their mortgages and file for bankruptcy under Chapter 13 and evaluate the model using new data on Chapter 13 bankruptcy filers. We also examine the effect of allowing bankruptcy judges to reduce debtors' mortgage payments, i.e., introducing "cram-down" of mortgages in Chapter 13.

We find that $96 \%$ of Chapter 13 filers are homeowners and $79 \%$ of filers repay mortgage debt in their repayment plans; while just $9 \%$ of filers repay only unsecured debt in their plans. These results suggest that filers use Chapter 13 almost exclusively as a "save-your-home" procedure. But under current law, only about $1 \%$ Chapter 13 filers save their homes when they would otherwise have defaulted. If cram-down were introduced, we predict that this fraction would increase to $10 \%$. The cost to lenders of introducing cram-down is estimated to be $\$ 264,000$ per home saved and $\$ 30$ billion in total.
\end{abstract}

Michelle J. White

Department of Economics

University of California, San Diego

La Jolla, CA 92093-0508

and NBER

miwhite@ucsd.edu

Ning Zhu

Graduate School of Management

UC, Davis

One Shields Avenue

Davis, CA 95616-8609

nzhu@ucdavis.edu 


\section{INTRODUCTION}

This paper has three goals. First, it examines how filing for bankruptcy under Chapter 13 helps financially distressed debtors save their homes. Chapter 13 helps debtors save their homes by stopping foreclosure, giving debtors extra time to repay mortgage arrears, and increasing their ability-to-repay their mortgages by discharging some or all of their unsecured debt. Second, the paper presents new evidence that nearly all debtors who use Chapter 13 are homeowners who wish to save their homes. This is despite the fact that a major bankruptcy reform adopted in 2005 was intended to force bankruptcy filers with higher incomes to repay some of their unsecured debt in Chapter 13. ${ }^{2}$

Third, the paper investigates how bankruptcy can be used to address the foreclosure crisis by allowing bankruptcy judges to "cram-down" (partially forgive) mortgage debt in Chapter 13 when debtors' mortgages exceed the value of their homes. The mortgage crisis has caused and continues to cause many homeowners to lose their homes. Housing pundits estimate that 2 to 3 million homeowners have lost their homes to foreclosure since 2007 and an additional 2 million are in default. In addition, fourteen million homeowners are current on their mortgage payments but might default because their mortgages are underwater. ${ }^{3}$ Foreclosures are very costly to both borrowers and lenders. Borrowers must bear the cost of relocating - their children must change schools, they lose their neighborhood ties, and some become homeless. Lenders lose because the transactions costs of foreclosure are high and homes fall in value while waiting to be resold.

\footnotetext{
${ }^{2}$ The 2005 bankruptcy reform (the "Bankruptcy Abuse Prevention and Consumer Protection Act”) instituted a means test that prevents higher-income debtors from filing under Chapter 7, where their unsecured debts would be discharged. See below for discussion. Ronald J. Mann, "Bankruptcy Reform and the 'Sweat Box' of Credit Card Debt." Univ. of Illinois Law Review, vol. 2007:1, 375-404 (2007), discusses the role of credit card lenders in writing and lobbying for the 2005 reform and Michelle J. White, "Bankruptcy Reform and Credit Cards," J. of Economic Perspectives, vol. 21, 175-199 (2007), discusses its economic effects.

${ }^{3}$ See Mark Zandi, “The Homeownership Vesting Plan,” December 22, 2008, www.economy.com/dismal/article_free.asp?cid=111220\&src; Center for Responsible Lending, "Updated Projections of Subprime Foreclosures in the United States and Their Impact on Home Values and Communities,” August 2008, http://www.responsiblelending.org/issues/mortgage/research/updated-projections-of-subprimeforeclosures-in-the-united-states-and-their-impact-on-home-values-and-communities.html, and Sheryl Stolberg and Edmund Andrews, "\$275 Billion Plan Seeks to Address Housing Crisis," New York Times, February 18, 2009.
} 
Foreclosures also harm neighborhoods because foreclosed homes cause blight and they harm localities by reducing property tax payments and squeezing local governments' budgets. ${ }^{4}$ Foreclosures also lead to yet more foreclosures by pushing down home prices, making it more difficult for homeowners to refinance and encouraging additional defaults.

Because foreclosure is costly to both borrowers and lenders, it would be in their joint interest to deal with the mortgage crisis by renegotiating mortgages rather than opting for default or foreclosure. But very few renegotiations have in fact occurred-reports from Moody's indicate that, of subprime loans coming up for interest rate increases, only 1\% were renegotiated in 2007 and 3.5\% in 2008. ${ }^{5}$ This is in part because most mortgages have been repackaged into mortgage-backed securities, where ownership is divided among multiple security-holders who have divergent interests. As a result, lenders are unlikely to agree on changes in the payment terms. ${ }^{6}$ In addition, all mortgages have a servicer who acts on owners' behalf, but mortgage servicing contracts compensate servicers only for the costs of foreclosing, not for the costs of renegotiating. These contracts also limit or prohibit servicers from changing the terms of the underlying mortgages. ${ }^{7}$ Another problem is that many homes in default have second mortgages, and second mortgage-holders can prevent modification or refinancing of first mortgages unless the second mortgage is paid off. Because many second mortgages are now worthless, lenders' best strategy is block modifications and refinancings unless they are paid for giving up their claims.

\footnotetext{
${ }^{4}$ Pew Charitable Trusts, "Defaulting on the Dream: States Respond to America's Foreclosure Crisis," 2008, www.pewtrusts.org/uploadedFiles/ wwwpewtrustsorg/Reports/Subprime_mortgages/defaulting_on_the_dream.pdf, estimates that foreclosures have caused the aggregate value of nearby homes to fall by around $\$ 350$ billion.

${ }^{5}$ Even when renegotiation occurs, lenders often just add the arrears to the mortgage, so that debtors' payments rise rather than fall. See Michael P. Drucker and William Fricke, "Moody's Subprime Mortgage Servicer Survey on Loan Modifications," Moody's Investors Service, September 2007, and Zandi, supra note 3.

${ }^{6}$ Mortgage-backed securities divide mortgages among multiple owners whose claims have different priorities. This means that any change in terms is likely to make one group of securityholders better off and others worse off.

${ }^{7}$ Servicers also keep late fees and penalties imposed on debtors in default, which means that they gain from foreclosing if they can collect the fees and they have little incentive to renegotiate if doing so means that the fees are dropped. See Katherine Porter, "Misbehavior and Mistake in Bankruptcy Mortgage Claims,” Texas Law Review, vol. 87 (2008), for a study of fees imposed by mortgage lenders on debtors in bankruptcy.
} 
The Bush Administration initiated a number of programs intended to encourage renegotiation of mortgages. These included a program to encourage voluntary renegotiations (“Hope Now”) and a program in which the Federal government would provide new, fixed-rate, 30-year mortgages to replace subprime mortgages ("Hope for Homeowners”) if the lender agreed to accept $85 \%$ of the current market value of the house. But virtually no renegotiations occurred under these programs. ${ }^{8}$ The Obama Administration recently proposed a new program, called “Home Affordable Modification," to address problems of debtors who are at risk of losing their homes. Under the program, if lenders reduce debtors' mortgage payments to 38\% of debtors' income, the Federal government will match additional reductions dollar-for-dollar to bring the mortgage payment down to $31 \%$ of debtors' income. To encourage servicers to modify mortgages, the program gives servicers \$1,000 for each mortgage modification plus additional payments up to $\$ 3,000$ if the debtor does not re-default on the modified mortgage. The program also pays lenders $\$ 1,500$ for each mortgage modification. ${ }^{9}$

A major stumbling block for both the Bush and Obama Administration programs is getting servicers and lenders to participate. The Bush Administration programs were unsuccessful because they allowed these groups to block any mortgage modifications or refinancing. The Obama administration program encourages both groups to participate by paying them, although the payments to lenders are small. But the program may still fail because it does not address the preference of first mortgage-holders for foreclosure over renegotiation or the blocking power of second mortgage-holders. First mortgage-holders generally do not favor modifying mortgages, because they predict that doing so will encourage many homeowners to demand modifications when they otherwise would repay their mortgages in full. Lenders face a mix of debtors who apply for mortgage modification because they cannot afford their mortgage payments and a larger number of debtors who apply strategically but would otherwise repay in full. Because

\footnotetext{
${ }^{8}$ Associated Press, “HUD Secretary Says Programs Are Ineffective," New York Times, November 20, 2008, page B3.

${ }^{9}$ Another Obama Administration program offers new, low-interest mortgages to homeowners, as long as their current mortgages are no more than 5\% underwater and are held by Fannie Mae or Freddie Mac. See Edmund I. Andrews, "Treasury Begins to Release Details of Loan Plan,” New York Times, March 4, 2009, and Department of the Treasury, "Making Home Affordable: Updated Detailed Program Description,” 2009, http://www.treas.gov/press/releases/reports/housing fact_sheet.pdf, for discussion.
} 
lenders cannot perfectly identify individual debtors' types, they gain from adopting a tough bargaining stance in which they never (or rarely) modify mortgages in order to discourage strategic behavior by debtors who would otherwise repay in full. But when lenders adopt a tough bargaining stance, the result is that debtors who cannot afford to repay end up in foreclosure. $^{10}$

In contrast, changing bankruptcy law so that bankruptcy judges could "cram-down” mortgages in Chapter 13 would prevent foreclosures even when servicers or lenders refuse to modify mortgages. It would therefore complement the new government programs to address the housing crisis. The Obama Administration has endorsed cram-down in bankruptcy for debtors who "have run out of options."11

In the paper, we first discuss the treatment of homeowners in Chapter 13 bankruptcy under current law. Then we develop a combined model of debtors' decisions to default on their mortgages and to file for bankruptcy under Chapter 13. The model is first used to examine the effect of a new (and probably unintended) subsidy to homeowners from unsecured creditors that was a result of the 2005 bankruptcy reforms. This subsidy reduces debtors' obligation to repay credit card and other unsecured debt by a dollar for each additional dollar of mortgage debt. We refer to it as the "credit card subsidy," since most unsecured debt is credit card debt. The model is then used to examine the effect of introducing mortgage cram-down in bankruptcy. We evaluate the model's predictions using a new dataset of debtors who filed for bankruptcy under Chapter 13 in 2006. The final section of the paper discusses policy implications.

The most important result of the paper is that Chapter 13 functions as a "save your home" bankruptcy procedure. This is evidenced by the fact that $96 \%$ of Chapter 13 filers are homeowners and $77 \%$ of debtors file under Chapter 13 voluntarily, rather than being forced to do

\footnotetext{
${ }^{10}$ See Christopher L. Foote, Kristopher Gerardi, and Paul S. Willen, "Negative Equity and Foreclosure: Theory and Evidence,” Journal of Urban Economics, 64(2), 2008, 234-245 for a study of Massachusetts housing markets during the downturn of the early 1990s. The authors found that less than $10 \%$ of debtors with underwater mortgages actually defaulted, presumably because lenders refused to modify their mortgages. See Michelle J. White, "Why Don’t More Households File for Bankruptcy?” J. of Law, Econ. and Org. 14, Oct. 1998, 205-231, for a model of this type applied to bankruptcy.

${ }^{11}$ See Department of the Treasury, “Making Home Affordable: Summary of Guidelines," March 4, 2009, http://www.ustreas.gov/press/releases/reports/guidelines_summary.pdf.
} 
so. Of those that file Chapter 13 repayment plans, 79\% repay mortgage arrears and 45\% repay car loans (some repay both), while just 9\% repay only unsecured debt. Although nearly all debtors who file under Chapter 13 do so in order to save their homes, our model suggests that the credit card subsidy causes less than $1 \%$ of them to save their homes when they would otherwise have defaulted. However introducing cram-down of mortgages in Chapter 13 would cause a 10fold increase in the number of Chapter 13 filers who save their homes. This is because the average cram-down subsidy is $\$ 134,000$ in present value terms-much higher than the average credit card subsidy of $\$ 10,000$.

\section{TREATMENT OF HOMEOWNERS IN BANKRUPTCY-CURRENT LAW AND PROPOSED REFORMS}

How does filing for bankruptcy help financially distressed homeowners save their homes? Filing for bankruptcy does not help homeowners directly, since under current law they must either repay their mortgages in full or give up their homes, regardless of whether they file or not. $^{12}$ Nonetheless bankruptcy helps homeowners in several ways. First, when debtors file under Chapter 13, mortgage lenders are stayed (prevented) from foreclosing during the bankruptcy procedure. Debtors can retain their homes by repaying the arrears on their mortgages - including past due interest, principle, and penalty payments — as part of a repayment plan that usually lasts for 5 years. They must also pay interest on the arrears and make all the normal mortgage payments that are due during the plan. Once the arrears are paid, the original mortgage contract is reinstated. Thus Chapter 13 gives financially-stressed debtors breathing space to save their homes. Car loans are treated the same way in Chapter 13, so that debtors can

\footnotetext{
12 Prior to 1993, bankruptcy judges had the power to cram-down mortgage loans. The prohibition on cram-down of mortgages in bankruptcy is based on the Supreme Court's decision in Nobleman v. American Savings Bank, 508 US 324 (1993) and on 11 U.S.C. § 1322(b)(2), which prevents bankruptcy judges from discharging any mortgage debt secured only by a primary residence, even if the value of the house is below the mortgage principle. 11 U.S.C. $\S$ 1322(c)(1) allows debtors to cure defaults on their mortgages in Chapter 13, as long as the residence has not been sold in foreclosure. For discussion, see George Bourguignon, "Interpretation of Bankruptcy Code 1322(c)(1): Arguing for a Bright-Line Approach to the Debtor's Statutory Right to Cure a Residential Mortgage Default. 7 U.C. Davis Bus. L.J. 461 (2007), pp. 461-496, and Adam J. Levitin and Joshua Goodman, "Mortgage Market Sensitivity to Bankruptcy Modification,” paper presented at the 2008 ALEA Conference, New York, law.bepress.com/cgi/viewcontent.cgi?article=2485\&context=alea.
} 
also use Chapter 13 to save their cars. ${ }^{13}$ Second, the bankruptcy trustee may help debtors challenge excessive fees and penalties imposed by lenders. ${ }^{14}$ Third, the credit card subsidy increases Chapter 13 filers' ability to repay their mortgages and/or car loans by discharging some or all of their unsecured debt. For each additional dollar that debtors owe on their mortgages and car loans, an additional dollar of unsecured debt is discharged in Chapter $13 .{ }^{15}$

In contrast, debtors who file for bankruptcy under Chapter 7 receive little help in saving their homes, because they are obliged to repay the entire mortgage immediately in order to prevent foreclosure. The same applies to car loans. But Chapter 7 is attractive to debtors who do not wish to save their homes or their cars, because their unsecured debt is discharged and they are not required to repay anything from their future incomes.

These rules imply that distressed homeowners who wish to save their homes are likely to file for bankruptcy under Chapter 13, while debtors who do not own homes are likely to file under Chapter 7. Previous evidence is consistent with this prediction. Eraslan, Li and Sarte (2007) found that over $80 \%$ of a sample of Chapter 13 filers in 2001-2002 were homeowners and Zhu (2007) found that $86 \%$ of a sample of Chapter 13 filers in 2003 were homeowners. In contrast, homeowning is much less important among Chapter 7 bankruptcy filers--Zhu (2007) found that only $47 \%$ of his sample of Chapter 7 bankruptcy filers in 2003 were homeowners. ${ }^{16}$

Prior to the 2005 bankruptcy reform, all debtors had the right to choose between Chapters 7 and 13. But the 2005 bankruptcy reform changed this by requiring some higher-income debtors to file under Chapter 13 and repay part of their unsecured debt from future income, if they file for bankruptcy at all. This change implies that, in theory, post-2005 Chapter 13 filers will

\footnotetext{
${ }^{13}$ Debtors must repay the entire car loan in full during their repayment plans. See William C. Whitford, “A History of the Automobile Lender Provisions of BAPCPA," Univ. of Illinois Law Review, vol. 2007:1, 143-194 (2007).

${ }^{14}$ Porter, supra note 7, found that mortgage lenders add questionable or excessive fees in half of all foreclosures.

${ }^{15}$ Some states allow debtors to prevent foreclosure outside of bankruptcy by curing defaults on their mortgages, but these programs usually require repayment of arrears more quickly than in Chapter 13. See Melissa Jacoby, "Homeownership Risk Beyond a Subprime Crisis: The Role of Delinquency Management,” Fordham Law Review 76, (2008).

${ }^{16}$ See Hulya Eraslan, Wenli Li, and Pierre-Daniel Sarte, "The Anatomy of U.S. Personal Bankruptcy Under Chapter 13,” working paper 07-31, Philadelphia Federal Reserve Bank, Sept. 2007, and Ning Zhu, "Household Consumption and Personal Bankruptcy," (2007), forthcoming, Journal of Legal Studies.
} 
consist of a mixture of financially distressed homeowners who file to save their homes and higher-income debtors who file because Chapter 13 is the only bankruptcy procedure open to them. We examine this issue in the empirical section below.

We also investigate the effects of introducing mortgage cram-down in Chapter 13. The legal theory of cram-down is that underwater mortgages can be divided into two parts: a secured part equal to the current market value of the house and an unsecured part equal to the mortgage principle minus current market value. Under cram-down, the unsecured part of the mortgage would be treated like any other unsecured loan and would be partly or fully discharged in Chapter 13. Adopting cram-down would equalize the treatment in bankruptcy of mortgages on debtors’ principle residences and other secured debts, since bankruptcy law already allows for cram-down of mortgages on rental properties and vacation homes. ${ }^{17}$

\section{II.MODEL}

In this section, we model debtors' decisions to file for bankruptcy and to default on their mortgages under current bankruptcy law. Suppose in period 0 debtors borrow an amount $P$ in the form of unsecured debt (such as credit card or medical debt), an amount $M$ in the form of a mortgage, and an amount $A$ in the form of an automobile loan. In period 1, debtors owe $P^{\prime}$, $M^{\prime}$, and $A^{\prime}$ on the three loans, respectively. $P^{\prime}, M^{\prime}$, and $A^{\prime}$ include the discounted present value of principle and interest payments, plus arrears, late fees, and penalties owed. In addition, $M^{\prime}$ and $A^{\prime}$ also include interest on the arrears and $M^{\prime}$ may include additional interest owed because the mortgage had a low initial "teaser” rate, but a higher rate thereafter. To keep the theory simple, we assume that debtors always repay their car loans in full. But in the empirical section below, we take account of the fact that debtors may give up their cars rather than repaying their car loans in bankruptcy.

Both housing value and debtors' incomes in period 1 are assumed to be uncertain. At the beginning of period 1 , the value of the house is drawn from a distribution and income is drawn from an independent distribution. The realized value of the house is denoted $V$ and realized income per year is denoted $Y$. To keep the model simple, housing value and income are

\footnotetext{
${ }^{17}$ However, cram-down of car loans was prohibited under the 2005 bankruptcy reform. See Whitford, supra note 13, and Levitin and Goodman, supra note 11.
} 
assumed to remain constant thereafter. ${ }^{18}$ Automobile value, in contrast, is known with certainty and is assumed to remain constant over time.

After learning $V$ and $Y$, debtors decide whether to default on their mortgages and whether to file for bankruptcy. Although most debtors are already behind on their mortgage payments at the time they file for bankruptcy, we use the term "default” to refer to debtors' decisions to abandon their homes and move to rental housing. If debtors default but do not file for bankruptcy, then mortgage lenders are assumed to foreclose on the house. If debtors default and file for bankruptcy under Chapter 13, mortgage lenders cannot foreclose during the bankruptcy procedure and debtors are allowed to remain in their homes while they repay mortgage arrears as part of their repayment plans.

If foreclosure occurs, the mortgage lender sells the house and the proceeds are used to pay, first, the cost of foreclosure, denoted $C_{f}$; second, the mortgage (first mortgage, then second mortgage); third, an amount up to the state's homestead exemption, denoted $X_{h}$, goes to the homeowner; and fourth, unsecured debt. ${ }^{19}$ All claims are paid in full until the proceeds of sale are exhausted. If anything remains after unsecured debt is repaid in full, it goes to the homeowner.

Debtors who file for bankruptcy must also pay bankruptcy costs of $C_{b}$, where $C_{b}$ includes lawyers' fees, filing fees, trustees' fees, and the cost of taking required credit counseling and debt management courses. We assume that debtors pay $C_{b}$ in full at the time of filing. ${ }^{20} C_{b}$ is assumed to be less than $P^{\prime}$, since otherwise debtors would never file for bankruptcy.

Now consider how debtors' obligation to repay in Chapter 13 is determined. Consider the mortgage first and suppose the payments are divided into two parts. The first part consists of

\footnotetext{
18 The model here is intentionally simplified because of the nature of the data on Chapter 13 bankruptcy filings. For dynamic models of bankruptcy, see Igor Livshits, James MacGee, and Michele Tertilt, "Consumer Bankruptcy: A Fresh Start,” American Economic Review, 97(1), 402-18, March 2007, and Eraslan, Li, and Sarte, supra note 16.

${ }^{19}$ If the house sells for less than the amount owed, then the mortgage lender may have an unsecured claim for the remainder. See Karen Pence, "Foreclosing on Opportunity: State Laws and Mortgage Credit,” Review of Economics and Statistics, vol. 88 (February 2006), pp. 177182, for discussion of which states prohibit mortgage lenders from making unsecured claims against debtors.

${ }^{20}$ Some bankruptcy costs are paid over the course of the repayment plan, rather than at the time of filing. We take account of this in the empirical section.
} 
arrears and interest on arrears, plus normal interest and principle payments owed during the 5year repayment period. The discounted present value of these payments is denoted $M_{1}^{\prime}$. The second part consists of normal interest and principle payments due from year 6 until the end of the mortgage contract. Assume that the mortgage contract has $N$ years remaining. The discounted present value of debtors' future mortgage payments from year 6 until year $N$ is denoted $M_{2}^{\prime}$. The present value of mortgage payments during and after the repayment plan sum to the present value of debtors' total mortgage payments, or $M_{1}^{\prime}+M_{2}^{\prime}=M^{\prime}$.

As an example, suppose the debtor has a 30-year mortgage with normal mortgage payments of $\$ 750$ per month or $\$ 9,000$ per year. As of the beginning of year 2 , the debtor owes arrears equal to four months of payments, or $\$ 3,000$, plus late fees, penalties, and interest on these payments that total $\$ 1,000$. She files for bankruptcy under Chapter 13. During the 5-year repayment period, she owes a total (undiscounted) of $5(\$ 45,000)+\$ 1,000=\$ 49,000$. $M_{1}^{\prime}$ equals the discounted present value of these payments, or approximately $\$ 45,000$ at a discount rate of 3 percent. From year 6 to year 28 (when the mortgage ends), the debtor owes $\$ 9,000$ per year. $M_{2}^{\prime}$ equals the discounted present value of these payments or approximately $\$ 139,000$ at the same interest rate. $\quad M^{\prime}$ therefore equals $\$ 184,000$.

The discounted present value of debtors' car payments during the repayment plan is $A^{\prime}$. We assume that debtors repay their car loans in full during the plan.

Now turn to debtors' obligation to repay unsecured debt in bankruptcy, which is the most complicated. Since the bankruptcy reform of 2005, debtors in bankruptcy have been subject to a "means test" that determines both whether they are allowed to file under Chapter 7 and, if not, their obligation to repay unsecured debt if they file for bankruptcy under Chapter 13. Under the means test, debtors first compute their yearly income, which equals their average monthly income during the six months prior to filing, multiplied by 12. Then they determine their yearly income exemption, denoted $X_{y}$, which is the amount of income they are allowed to keep for their living expenses each year while they are in Chapter 13. Finally, they compute their disposable income, which equals income minus the income exemption. If debtors' disposable income is below $\$ 1,200$ per year, then they are allowed to file under Chapter 7 and, if they choose to file under Chapter 13, then they are not required to repay any of their unsecured debt. If their disposable income is above \$2,000 per year, then they must file under Chapter 13 if they 
file for bankruptcy at all and they must use all of their disposable income for 5 years to repay debt. $^{21}$

Now consider how the income exemption $X_{y}$ is calculated. The minimum value of the income exemption equals the median family income level in the debtor's state of residence, adjusted for family size. This means that debtors whose income is below the state median income level plus $\$ 1,200$ are allowed to file for bankruptcy under Chapter 7 . But debtors whose income is above the state median level must calculate their income exemption by adding up various allowances for living expenses. There is an allowance for rent, an allowance for transportation, and an allowance for personal expenditures. ${ }^{22}$ There are also additional allowances for some or all of debtors' actual expenditures on taxes, mandatory payroll contributions, insurance, telecommunications costs, childcare, child support, children's educational expenses, care of elderly or disabled relatives, and home security costs. Finally, debtors also add their secured debt payments during the plan to the income exemption.

In our notation, a particular debtor's disposable income during the 5-year Chapter 13 repayment period equals $5\left(Y-X_{y}\right)$ if she has no secured debt, and $5\left(Y-X_{y}\right)-A^{\prime}-M_{1}^{\prime}$ if she has a mortgage or a car loan or both. ${ }^{23}$ Thus when debtors have mortgages or car loans, the amount of unsecured debt they must repay falls. For each additional dollar of secured debt payments, a dollar of additional unsecured debt payments is discharged, until debtors' obligation to repay unsecured debt falls to zero. The procedure of increasing the income exemption by the amount of secured debt payments increases debtors' ability to repay their mortgages, thus making it easier for them save their homes. It also increases debtors' ability to save their cars. We refer to the increase in the income exemption due to secured debt obligations as the credit

${ }^{21}$ If debtors' disposable income is between \$1,200 and \$2,000 per year, they are allowed to file under Chapter 7 if their unsecured debt is more than four times their disposable income per year. ${ }^{22}$ The procedure for determining the income exemption is based on Internal Revenue Service procedures for collecting from delinquent taxpayers, but is more generous to debtors. See Michelle J. White, “Abuse or Protection: The Economics of Bankruptcy Reform Under BAPCPA,” Univ. of Illinois Law Review, 2007, pp. 275-304, for discussion of the means test. Entrepreneurs are not subject to the means test and can file under Chapter 7 regardless of their incomes.

${ }^{23}$ For simplicity, we do not discount $Y$ or $X_{y}$. This is equivalent to assuming that $Y$ and $X_{y}$ increase each year at a rate equal to the discount rate. 
card subsidy. ${ }^{24}$ The subsidy equals $\max \left[\min \left[5\left(Y-X_{y}\right), P^{\prime}\right], 0\right]$ -

$\max \left[\min \left[5\left(Y-X_{y}\right)-M_{1}^{\prime}-A^{\prime}, P^{\prime}\right], 0\right]$. It is more valuable when debtors have more unsecured debt and higher mortgages or car loans. ${ }^{25}$

In addition to their obligation to use their disposable income to repay, some Chapter 13 filers are also obliged to use their home equity to repay. Suppose a debtor has income below the state median level, so that all of her future income is exempt. But suppose the value of her house $V$ exceeds $M^{\prime}+X_{h}+C_{f}$, which means that selling the house would generate enough money to repay at least some of her unsecured debt. The "best interest of creditors" test requires that unsecured creditors receive at least as much in Chapter 13 as they would in Chapter $7 .{ }^{26}$ Therefore since unsecured creditors would receive $V-M^{\prime}-X_{h}-C_{f}$ if the debtor filed under Chapter 7, she must repay at least this amount in Chapter 13. The "best interest of creditors" test means that even low-income debtors will avoid filing under Chapter 13 if the value of their homes is sufficiently high that they would have to repay all of their unsecured debt in bankruptcy, or if $V-M^{\prime}-X_{h}-C_{f}+C_{b} \geq P^{\prime}$.

Debtors' alternate housing cost is denoted $R^{\prime}$. It equals the present value of the cost of moving to rental housing in period 1 and paying rent for the next $N$ years.

\section{A. Default and Bankruptcy Decisions under Current Law}

Now consider debtors' bankruptcy and default decisions in period 1. Debtors are assumed to make these decisions so as to maximize the discounted present value of their wealth defined over the next $N$ years, i.e., until the end of the mortgage contract. However, debtors are assumed to have no financial wealth other than their home equity and, as a result, they may be subject to liquidity constraints that prevent them from making wealth-maximizing choices. ${ }^{27}$ Debtors

\footnotetext{
${ }^{24}$ Prior to 2005, there was no credit card subsidy because there was no means test to determine how much debtors were obliged to repay in Chapter 13.

${ }^{25}$ Jeremy Berkowitz and Richard Hynes, "Bankruptcy Exemptions and the Market for Mortgage Loans,” J. of Law \& Economics, 42, 809-830 (1999) first suggested that filing for bankruptcy increases debtors' ability to repay their mortgages by reducing their unsecured debt obligations. 26 11 U.S.C. § 1307 (2000).

27 The assumption that debtors maximize their wealth in making their default and bankruptcy decisions is referred to as the "ruthless" decision model. There is empirical evidence supporting ruthless decision models of both default and bankruptcy, although these models also suggest that
} 
choose among four alternatives: default on their mortgages and file for bankruptcy (abbreviated D/B), default but do not file for bankruptcy (D/NB), do not default but file for bankruptcy (ND/B), and neither default nor file for bankruptcy (ND/NB). We consider debtors' decisions under current law first. Then we modify the model to consider how their decisions would change if mortgage cram-down were introduced in Chapter 13.

Figure 1 shows debtors' decisions. Income $Y$ is shown on the horizontal axis and housing value $V$ on the vertical axis. The figure is divided into four regions that correspond to the four choices. In this section, we describe each of the four regions intuitively; details are given in the theoretical appendix.

Consider the default decision first. The basic condition for debtors to default is that the present value of the cost of owning $M^{\prime}-V$ exceeds the present value of the cost of renting, $R^{\prime}$, or $V<M^{\prime}-R^{\prime}{ }^{28}$ However if debtors receive the credit card subsidy, then their cost of owning falls from $M^{\prime}-V$ to as low as $M_{2}^{\prime}-V$. As a result, they may keep their homes even when $V$ is below $M^{\prime}-R^{\prime}$. On the other hand, debtors who are liquidity-constrained may default when $V$ exceeds $M^{\prime}-R^{\prime}$. We assume that debtors are willing to devote up to half of their incomes to pay the cost of their Chapter 13 repayment plans, which during the first year is $C_{b}+\left(M_{1}^{\prime}+A^{\prime}\right) / 5$. Debtors are assumed to be liquidity-constrained and forced to default if their incomes are below this amount. The income level at which debtors are indifferent between defaulting versus not defaulting is denoted $Y^{D}$. Figure 1 shows that $Y^{D}$ varies depending on the value of debtors' homes and their incomes.

many debtors do not behave ruthlessly. For empirical models of bankruptcy and default, see Scott Fay, Erik Hurst, and Michelle J. White, “The Household Bankruptcy Decision,” American Economic Rev., 92, June 2002, 708-718, John M. Quigley and Robert Van Order, "Explicit Tests of Contingent Claims Models of Mortgage Default,” Journal of Real Estate Finance and Economics, 11: 99-117 (1995), and Foote et al, supra note 10.

${ }^{28}$ Note that this default condition is quite different from the usual assumption that debtors default when their mortgages are underwater, which means that $V<M$. In addition to $V$ and $M$, the default decision also depends on interest and discount rates, which are incorporated in $M^{\prime}$, and on the present value of the cost of rental housing. If future housing values and/or rental costs are uncertain, then there is also an option value to delaying the default and bankruptcy decisions. 
Now turn to debtors' decisions to file for bankruptcy. Debtors prefer to file for bankruptcy if their gain from filing exceeds bankruptcy costs $C_{b}$. For debtors who default on their homes and whose incomes are below the state median level, the gain from filing is the value of unsecured debt $P^{\prime}$, since all of it is discharged in bankruptcy. But debtors' gain from filing is higher if they receive the credit card subsidy and is lower if the best interest of creditors test forces them to repay more of their unsecured debt. The income level at which debtors are indifferent between filing versus not filing for bankruptcy is denoted $Y^{B}$. Figure 1 shows that $Y^{B}$ also depends on both the value of debtors' homes and on their incomes.

In figure 1, the default/bankruptcy region $\mathrm{D} / \mathrm{B}$ is outlined in heavy black lines and is divided into two parts by a dashed line. Below the dashed line, housing value and income are both low. Debtors default because the cost of owning exceeds the cost of renting (so that $V<M^{\prime}-R^{\prime}$ ) and they file for bankruptcy because the gain from having their unsecured debt discharged exceeds bankruptcy costs $\left(P^{\prime}>C_{b}\right)$. Above the dashed line, debtors still gain from filing for bankruptcy because income is low, but they wish to save their homes because housing value is higher. Debtors are liquidity-constrained if housing value is between $M^{\prime}-R$ and $M^{\prime}+X_{h}+C_{f}$ and if they cannot afford their repayment plans during the first year even if they spend half of their incomes on housing (so that $.5 Y<C_{b}+\left(M_{1}^{\prime}+A^{\prime}\right) / 5$ ). Since liquidity-constraints are important to our analysis, this portion of the D/B region is labeled as "Group I."

The default/no bankruptcy region $\mathrm{D} / \mathrm{NB}$ occurs where housing values are less than $M^{\prime}-R^{\prime}$, so that debtors prefer to default rather than save their homes. But they do not file for bankruptcy because their incomes are above $Y^{B}$.

The no default/no bankruptcy region ND/NB occurs where both housing value and income are high. Debtors prefer to save their homes because the cost of renting exceeds the cost of owning $\left(V>M^{\prime}-R^{\prime}\right)$ and they prefer to avoid bankruptcy because their incomes are sufficiently high that the gain from filing is less than the cost. ${ }^{29}$

${ }^{29}$ The ND/NB region is assumed to include the area where $V$ is very high, but $Y$ is low. In this area, debtors are liquidity-constrained and unable to pay their mortgages, but the value of their homes is so high that they would not gain from filing under Chapter 13. We assume that they sell their homes outside of bankruptcy. 
Finally, the no default/bankruptcy region ND/B occurs where housing value and income both have intermediate values. All debtors in this region file for bankruptcy and keep their homes, so that they receive the credit card subsidy. The ND/B region is also divided in two parts by a dashed line. Below the dashed line, housing value is less than $M^{\prime}-R^{\prime}$ and debtors would therefore default, but the credit card subsidy causes them to save their homes. If we view the credit card subsidy as a policy to encourage debtors to save their homes, then the lower part of the ND/B region is the area where the policy succeeds; it is labeled "group II." In the upper part of the ND/B region, housing value exceeds $M^{\prime}-R^{\prime}$. Here housing value is sufficiently high that debtors would save their homes even without the subsidy. This area, labeled "group III," is where debtors receive the subsidy, but it does not change their behavior. ${ }^{30}$

Overall, the credit card subsidy reduces default, but at the cost of encouraging more debtors to file for bankruptcy and subsidizing some debtors who would have saved their homes anyway. In the empirical section below, we estimate the size of groups I, II and III.

\section{B. Default and Bankruptcy Decisions Under Cram-down}

Now consider how changing bankruptcy law to allow cram-down of mortgages in Chapter 13 would affect debtors' default and bankruptcy decisions. In particular, suppose bankruptcy judges reduce debtors’ mortgage payments by multiplying payments times $V$ / $M$ whenever the mortgages are underwater, i.e., when $V / M<1$. The reduction is assumed to apply to mortgage payments both during and after the Chapter 13 repayment plan, so that $M_{1}^{\prime}$ is replaced by $(V / M) M_{1}^{\prime}$ and $M_{2}^{\prime}$ is replaced by $(V / M) M_{2}^{\prime} \cdot{ }^{31} \quad$ All other aspects of bankruptcy law are assumed to remain the same and debtors are assumed to make their default and bankruptcy decisions in the same way. Note that while the cost of the credit card subsidy is borne by unsecured lenders, the cost of cram-down is borne by mortgage lenders.

The main changes caused by cram-down are as follows. First, fewer debtors are liquidity constrained, because Chapter 13 repayment plans become less costly. In figure 1, this means that

\footnotetext{
${ }^{30}$ Not all debtors have an ND/B region. If the credit card subsidy is small because debtors have little unsecured debt or small mortgages, then $Y^{D}$ may exceed $Y^{B}$.

${ }^{31}$ To discourage debtors from presenting biased assessments of the decline in home value, the reduction in the mortgage principle could be based on an objective measure, such as the decline in the S\&P/Case-Schiller housing value index for the relevant metropolitan area over the period since the mortgage was issued.
} 
the right-hand boundary of the D/B group I region shifts to the left, making the region smaller. Second, debtors' gain from filing for bankruptcy increases, because cram-down reduces their mortgage payments. As a result, $Y^{B}$ increases, more debtors file for bankruptcy and the righthand boundary of the ND/B region shifts to the right. This increases the number of debtors in the ND/B groups II and III. Third, the lower boundary of the ND/B region shifts downward. This is because cram-down reduces the cost of owning, while leaving the cost of renting unaffected. As a result, debtors who own low-value houses are less likely to default. The overall effect of these changes is that fewer debtors default.

Now consider how the introduction of cram-down affects the size of groups I, II and III. Group I-debtors who default because they are liquidity-constrained-becomes smaller. Group II-composed of debtors who save their homes under cram-down but would otherwise have defaulted-now includes two sets of debtors. One is those in the lower part of the ND/B region, while the other consists of debtors who previously were liquidity-constrained, but now save their homes because of cram-down. Group III-composed of debtors who receive cram-down and/or the credit card subsidy but would have saved their homes anyway-includes all debtors in the upper part of the ND/B region.

\section{CHARACTERISTICS OF CHAPTER 13 BANKRUPTCY FILERS}

We collected a new dataset of all Chapter 13 bankruptcy filings in Delaware in 2006-there were 586 filings in total. The data are taken from both the forms that debtors submit at the time of filing and from their repayment plans, which are filed later. We used filings in Delaware because the Delaware bankruptcy court has been a leader in making bankruptcy filings publicly available and because Delaware filers are fairly representative of bankruptcy filers nationally. ${ }^{32}$

The importance of Chapter 13 as a save-your-home bankruptcy procedure is illustrated by the facts that $96 \%$ of Chapter 13 filers in our sample are homeowners and $77 \%$ pass the means

32 Debtors' filing forms and repayment plans are available through the Bankruptcy Courts' online PACER system. For bankruptcy forms, see http://www.uscourts.gov/rules/Revised_Rules_and_Forms/BK_Form_B22C_101105.pdf. Zhu, supra note 16, presents evidence that Delaware filers are representative of bankruptcy filers nationally. 
test, which means that they filed under Chapter 13 voluntarily. ${ }^{33}$ (See table 1.) The average home value is $\$ 197,000$ for homeowners and the average level of mortgage debt for those who list mortgages at filing is $\$ 154,000$. Average home equity for all homeowners is nearly $\$ 40,000$ and equity is positive for $71 \%$ of homeowners. Because average home equity is positive, most debtors in the sample have an incentive to save their homes, although liquidity constraints may limit their ability to do so.

Turning to other debts, $57 \%$ of debtors list car loans at filing and the average car loan is $\$ 18,400 ; 52 \%$ list priority debt (taxes owed) at filing and the average debt is $\$ 8,500 ; 89 \%$ of debtors list unsecured loans and the average unsecured debt is $\$ 29,800$; while $16 \%$ list student loans and the student loan is $\$ 15,000$.

Now turn to debtors' Chapter 13 repayment plans. We located repayment plans for $90 \%$ of Chapter 13 filers. Among the remainder, some may have abandoned their efforts to save their homes and shifted their bankruptcy filings to Chapter 7, while others may have repaid their mortgage arrears without filing a repayment plan-perhaps after successfully renegotiating their mortgages with lenders. Among plan filers, 79\% propose to repay mortgages, $45 \%$ propose to repay car loans, $9 \%$ propose to repay priority debt, $42 \%$ propose to repay unsecured loans, and only $0.6 \%$ propose to repay student loans. ${ }^{34}$

Around 9\% of Chapter 13 filers propose to repay only unsecured debt in their repayment plans and these plans raise the issue of why debtors filed under Chapter 13 in the first place. Nearly two-thirds of debtors in this group passed the means test and could have filed under Chapter 7, so that high incomes did not force them to file under Chapter 13 . But 82\% were homeowners and their average home equity was $\$ 56,000$. Of these debtors, more than one-third had home equity that exceeded the Delaware homestead exemption of $\$ 50,000$. Thus some

\footnotetext{
${ }^{33}$ We categorize debtors as homeowners if they give the value of their homes or the amount of the mortgage on their filing forms or, because this data is sometimes missing, if they repay a mortgage in their repayment plans. Because mobile home loans are listed as mortgages on bankruptcy forms, owners of mobile homes are categorized as homeowners.

${ }^{34}$ Student loans cannot be discharged in Chapter 13 unless the judge decides that repaying them would constitute an "undue hardship” (11 U.S.C. § 523 (a)(8)). Some filers in our sample presumably obtained hardship discharges. Those who did not probably avoided putting their student loans into their repayment plans, since they are not required to do so and paying student loans as part of a plan subjects them to the trustee's $10 \%$ fee. These factors explain why few repayment plans include student loans.
} 
debtors who repaid only unsecured debt in Chapter 13 probably did so because if they filed under Chapter 7, they would have been obliged to sell their homes in bankruptcy.

The average lawyer's fee in our sample is around $\$ 2,800$. In addition, debtors must pay a bankruptcy court filing fee of $\$ 274$ and they must take both credit counseling and debt management courses at a minimum cost of $\$ 100$. Bankruptcy trustees also impose a fee of $10 \%$ of the amount paid under the repayment plan; the average trustee's fee in the sample-assuming that debtors complete their repayment plans_-is $\$ 2,900$. Our evidence thus suggests that filing under Chapter 13 costs the average debtor over $\$ 3,000$ and costs rise to $\$ 6,000$ for debtors who complete repayment plans. ${ }^{35}$

Do higher-income debtors file under Chapter 13 because the means test prevents them from filing under Chapter 7, rather than to save their homes? We found little difference in our sample between higher-income debtors (those who have too much disposable income to file under Chapter 7) versus lower-income debtors in the rate of homeowning. But we found that higherincome debtors are more likely to repay mortgage debt and less likely to repay only unsecured debt in their plans. These results suggest that higher-income debtors, like lower-income debtors, file under Chapter 13 in order to save their homes.

\section{SIMULATION RESULTS}

Now turn to the simulation of the model in figure 1 . We collected or constructed data for the variables $Y, X_{y}, V, M, M^{\prime}, M_{1}^{\prime}, M_{2}^{\prime}, P^{\prime}, A^{\prime}$ and $C_{b}$. For the homestead exemption $X_{h}$, we use the Delaware value of $\$ 50,000$. We assume that the cost of foreclosure $C_{f}$ equals $30 \%$ of housing value. The number of years in the future that debtors take into account in making their decisions, $N$, is assumed to be 28-equal to the length of a 30-year mortgage obtained two years previously. To construct the present value of future mortgage payments, we assume the mortgage interest rate to be .06 and debtors' discount rate to be .03 . To construct the cost of alternate rental housing $R^{\prime}$, we assume that debtors spend $25 \%$ of their incomes on rent ${ }^{36}$ and we assume a one-time moving cost, payable immediately, of $\$ 2,000$. We then convert rent

${ }^{35}$ If debtors do not complete their repayment plans, they do not receive a discharge and creditors may resume their collection efforts.

${ }^{36}$ This is the median rent-to-income ratio in Delaware. See U.S. Census Bureau, Statistical Abstract of the United States 2004-2005, 124 ${ }^{\text {th }}$ edition (2005), table 958. 
payments into present value assuming that the rate of increase in rent equals the discount rate. In constructing $A^{\prime}$, we include priority debts and lawyers' fees as well as automobile loans, because these debts are repaid before other unsecured debts and they therefore increase the credit card subsidy. ${ }^{37}$ We exclude observations that have no repayment plan, where the debtor is not a homeowner, or where information about mortgage payments under the plan is missing. With these exclusions, the sample size falls to 436. The data appendix gives details concerning how we constructed the variables and table 2 shows summary statistics for debtors who file repayment plans in Chapter 13.

Then for each debtor, we calculate the boundaries of each of the regions in figure 1 and determine in which region the debtor is predicted to locate. Column (1) of table 3 gives the results in the base case. $92 \%$ of debtors are predicted to file for bankruptcy, which is close to the $100 \%$ that actually file. $57 \%$ of debtors are predicted to default, even though only $15 \%$ of debtors have underwater mortgages. We attempted to check the accuracy of the model's predictions of default by examining whether, as of the fall of 2008, debtors were still listed in online telephone directories at the same address as shown in their bankruptcy filings. Otherwise we classified them as defaulting. This procedure is likely to overestimate default, since some debtors have unlisted telephone numbers and others may have sold their homes and moved without defaulting. Of those who are predicted to default, 58\% actually defaulted; while of those who are predicted to save their homes, $46 \%$ defaulted. The fact that debtors are more likely to default if they are predicted to do so supports the model. But the fact that many debtors do the opposite of what the model predicts suggests that debtors often do not act in their own financial interest. $^{38}$

\footnotetext{
${ }^{37}$ Priority debts are non-dischargeable in bankruptcy and Chapter 13 filers must pay them in full as part of their repayment plans, unless debtors' disposable income is exhausted by repaying secured debt (11 U.S.C. § 1322(a)). The same treatment applies to lawyers’ fees that are not paid in advance.

${ }^{38}$ Sarah Carroll and Wenli Li, The Homeownership Experience of Households in Bankruptcy," Philadelphia Federal Reserve Bank, working paper 08-14, August 2008, find that among homeowners who file for bankruptcy, 30 to 40 percent experience foreclosure. Their study does not distinguish between homeowners according to whether they gain financially from saving their homes versus defaulting.
} 
Now consider the results for groups I, II and III in the base case. About one-third of debtors are in group I, i.e., they default because they are liquidity-constrained. Compared to all debtors in the sample, they have above-average home equity levels and mortgage payments, but below-average incomes. Their credit card subsidies if they saved their homes would be only $\$ 2,900$ on average, which does not loosen the liquidity constraint enough to allow them to save their homes. Now turn to group II debtors, who save their homes due to the credit card subsidy when they otherwise would have defaulted. Less than $1 \%$ of debtors are in this group. Their average credit card subsidy in present value terms is $\$ 44,900$, or around $7 \%$ of the present value of future mortgage payments. These debtors are unusual because their unsecured debt and their mortgage payments are both extremely high and this makes their credit card subsidies high. They also have unusually high incomes--\$71,400 — compared to an average income level of $\$ 42,600$. Finally, group III debtors receive the credit card subsidy, but would have kept their homes anyway. $37 \%$ of debtors fall in this group and their average credit card subsidy is $\$ 4,500$, or $1.2 \%$ of the present value of future mortgage payments. These debtors can afford to save their homes because they have above-average incomes and below-average mortgage payments compared to bankruptcy filers generally.

Thus even though 96\% of debtors in Chapter 13 are homeowners, the credit card subsidy causes very few of them to save their homes when they otherwise would have defaulted. Those who do save their homes receive unusually high credit card subsidies. The credit card subsidy also goes to many debtors who would have saved their homes anyway. Because very few debtors change their default decisions, $85 \%$ of subsidy dollars go to debtors who would have saved their homes anyway. Overall, the credit card subsidy is not an effective program for reducing foreclosures.

In column (2) of table 3, we rerun the simulation assuming that all debtors' homes have fallen in value by $25 \%$. This represents the current situation in which housing have fallen sharply, but bankruptcy law remains unchanged. ${ }^{39}$ With lower housing values, the percent of debtors in the sample whose mortgages are underwater increases from .15 to .56 and the average level of home equity falls from $\$ 45,000$ to $-\$ 3,200$. But the proportion of debtors who are

\footnotetext{
39 The 25\% figure equals the decline in the S\&P/Case-Schiller index of home values for 20 U.S. metropolitan areas from July 2006 to November 2008. See http://www2.standardandpoors.com /portal/site/sp/en/us/page.topic/indices_csmahp/0,0,0,0,0,0,0,0,0,1,1,0,0,0,0,0.html.
} 
predicted to file for bankruptcy increases only slightly, from .92 to .94, and the proportion who are predicted to default increases only slightly, from .57 to .59. The fraction of debtors who are liquidity-constrained (group I) falls sharply from .32 to .18. This is because, with lower housing values, many debtors who previously defaulted because they were liquidity-constrained now default because the cost of owning (which rises when housing values fall) now exceeds the cost of renting. The fraction of debtors in group II, who save their homes because of the credit card subsidy, falls even further and the proportion of debtors in group III, who receive the credit card subsidy but would have saved their homes anyway, remains about the same. These results suggest that the credit card subsidy is no more effective as a policy for dealing with the mortgage crisis when housing values fall.

Now turn to the results when we introduce cram-down of mortgages in bankruptcy, shown in column (3) of table 3. Everything else is assumed to remain the same, so that debtors may receive the credit card subsidy as well as cram-down. As discussed above, we assume that cramdown reduces debtors' mortgage payments by the ratio of house value (reduced by $25 \%$ ) to the mortgage principle, so that $M_{1}^{\prime}$ and $M_{2}^{\prime}$ are both multiplied by .75V / $M$, if this ratio is less than one. The average value of $.75 \mathrm{~V} / \mathrm{M}$ is .89 , so that cram-down reduces the average debtor's future mortgage payments by $11 \%$. The introduction of cram-down sharply reduces debtors' probability of default, from .59 to .50, but it has no effect on their probability of filing for bankruptcy.

Now consider how cram-down affects the three groups of debtors. Group I falls from .18 to .14 of all debtors, because cram-down loosens liquidity constraints by reducing debtors' mortgage payments. If those debtors who remain liquidity-constrained instead saved their homes, they would receive mortgage subsidies averaging \$3,000 and cram-down subsidies averaging $\$ 2,900$. But these subsidies are too small to allow them to avoid default.

Group II now includes two separate sets of debtors who would otherwise have defaultedthose in the lower part of the ND/B region and those who previously were liquidity-constrained, but save their homes once cram-down is introduced. A combined total of $10.2 \%$ of all debtors now save their homes when they would otherwise have defaulted. But the cost of cram-down is high. Cram-down cuts the mortgage payments of group II debtors by $\$ 134,000$ in present value terms, for an average reduction of $27 \%$. In addition, these debtors receive credit card subsidies averaging $\$ 10,000$, for a combined total subsidy of $\$ 144,000$ in present value terms. Debtors in 
group II have above-average incomes--\$65,000 compared to an overall average of $\$ 42,600$. Thus debtors who save their homes as a result of cram-down are well-off compared to all debtors in Chapter 13 and they receive very large subsidies. But only large subsidies would cause them to save their homes, since their average home equity is $-\$ 74,000 .{ }^{40}$

Finally, the proportion of debtors in group III rises from .38 to .42 when cram-down is introduced. These debtors would have saved their homes anyway, but they receive an average cram-down subsidy of $\$ 31,600$ and an average credit card subsidy of $\$ 4,500$. They have aboveaverage incomes and slightly negative home equity of $-\$ 3,400$.

These simulations suggest several results. First, the credit card subsidy by itself has little effect on whether debtors save their homes: less than one percent of Chapter 13 filers save their homes when they would otherwise have defaulted. Second, cram-down is much more effective as a save-your-home policy - the proportion of Chapter 13 filers who save their homes rather than defaulting rises from less than $1 \%$ to more than $10 \%$ when cram-down is introduced. But cram-down is costly to mortgage lenders: on average, each debtor who saves his/her home rather than defaulting receives a transfer of $\$ 134,000$ in present value terms and, for each debtor who saves his/her home, 4.1 additional debtors who would have saved their homes anyway receive transfers of $\$ 31,600$. Thus the total cost of cram-down per home saved is $\$ 264,000$ in present value terms.

The final step in the analysis would normally be to project how many homes would be saved if cram-down were introduced in Chapter 13 and the total cost to both mortgage and unsecured lenders. But our dataset is not suitable for projecting the number of additional homes saved, since it covers only debtors who filed for bankruptcy when cram-down was not in effect. If cram-down were introduced, the large subsidies are likely to result in many additional bankruptcy filings by debtors whose characteristics may be quite different from those in our sample. However the Congressional Budget Office recently estimated that 350,000 additional bankruptcy filings would occur over the next several years if cram-down of mortgages in

\footnotetext{
${ }^{40}$ Within group II, debtors with higher incomes receive larger subsidies. The average combined cram-down plus credit card subsidy is $\$ 77,000$ for those in the lowest quartile, $\$ 117,000$ in the two middle quartiles, and $\$ 252,000$ in the highest quartile. A similar pattern applies to group III debtors.
} 
bankruptcy were adopted. ${ }^{41}$ We can use this figure to estimate the cost of cram-down and the credit card subsidy. Suppose we assume that all of the additional bankruptcy filings would be by debtors in groups II and III, that the relative proportions of group II versus group III filers would be the same as in our sample, and that filers in each group would receive the same average subsidies as in our sample. Then the aggregate cost of introducing cram-down in present value terms would be $\$ 18$ billion to mortgage lenders plus $\$ 2$ billion to unsecured lenders. In addition, 359,000 Chapter 13 bankruptcy filings occurred in 2008, and these debtors are also eligible to receive the cram-down subsidy. Assume that they have the same likelihood of receiving cramdown as debtors in our sample. Then the cost of providing the cram-down subsidy to debtors who would have filed for bankruptcy anyway is an additional $\$ 10$ billion per year. This suggests that the total cost of introducing cram-down over the next several years would be around $\$ 28$ billion to mortgage lenders, plus an additional $\$ 2$ billion to unsecured lenders. ${ }^{42}$

\section{V.CONCLUSION}

The most important result of the paper is that Chapter 13 functions as a "save your home" bankruptcy procedure. This is evidenced by the fact that $96 \%$ of Chapter 13 filers are homeowners and 77\% of debtors file under Chapter 13 voluntarily, rather than being forced to do so. Although nearly all debtors who file under Chapter 13 do so in order to save their homes, our model suggests that the credit card subsidy causes less than $1 \%$ of them to save their homes when they would otherwise have defaulted. However if cram-down of mortgages in Chapter 13 were introduced, the proportion of Chapter 13 filers who save their homes rather than defaulting

${ }^{41}$ The version of cram-down in the proposed legislation is similar to the assumptions in our model. The proposed legislation is H.R. 200: Helping Families Save Their Homes in Bankruptcy Act of 2009. It allows bankruptcy judges to reduce underwater mortgages to the current market value of the house. The bill requires that debtors first attempt to have their mortgages modified through the new non-bankruptcy foreclosure-prevention programs. See Congressional Budget Office, Cost Estimate: H.R. 200, February 23, 2009, www.cbo.gov/ftpdocs/100xx/doc10007/hr200.pdf.

42 The figures for the cost of cram-down are 350,000((.42/.52)\$31,600+(.10/.52)\$134,000) for additional filings and $359,000(.42 * \$ 31,600+.10 * \$ 134,000)$ for bankruptcy filings that would have occurred anyway. The figure for the cost of providing the credit card subsidy to additional filers is $350,000((.42 / .52) \$ 4,500+(.10 / .52) \$ 10,000)$. Debtors who would have filed anyway already receive the credit card subsidy, so that there is no additional cost from adopting cramdown. 
would increase ten-fold. For these debtors, cram-down reduces future mortgage payments by an average of $\$ 134,000$, while for debtors who receive the subsidy but would have saved their homes anyway, cram-down reduces future mortgage payments by $\$ 31,600$ (both figures are in present value terms). We estimate that the aggregate cost to mortgage and unsecured lenders of introducing cram-down would be around $\$ 30$ billion.

Two caveats should be emphasized. First, although we argued that foreclosures are socially costly and preventing them is efficient, this does not mean that preventing every foreclosure is necessarily efficient. Some debtors may have bought homes that they cannot afford or may have experienced permanent income losses that make their current homes unaffordable. These homes would be more highly valued by alternative occupants and it would be economically efficient to transfer them. The analysis in this paper does not address the normative questions of how many homes should be saved and whether introducing cram-down would mainly save homes that should or should not be saved.

A second point is that the cost of cram-down and the number of additional bankruptcy filings that would occur if cram-down were adopted both depend heavily on the new non-bankruptcy foreclosure-prevention programs that are just starting to operate. The recently-announced “Home Affordable Modification” program to avoid foreclosures requires that mortgage lenders bear the full cost of reducing debtors' mortgage payments to 38\% of their incomes, plus half of the additional cost of reducing debtors' mortgage payments to $31 \%$ of their incomes. For many debtors, this program is likely to be more attractive than filing under Chapter 13 and receiving the cram-down subsidy. If so, then the number of additional bankruptcy filings will be small. But if lenders refuse to modify mortgages outside of bankruptcy-as they have under previous government programs - then the number of additional bankruptcy filings could be much higher. 


\section{Data Appendix:}

\section{Explanation of Variables Used in the Simulation}

$V$ : house value. This is the debtor's figure for the market value of the house, taken from Schedule A, "Real Property." When house value is missing, we assume it equals the value of assets (from the Summary of Schedules, bottom figure) minus the amount of the debtor's automobile loan (from Schedule D).

Y: debtor's income per year. The income figure is taken from Schedule I, "Current Income of Individual Debtor(s)." If this figure is missing, we use the income figure given on Form B22C, line 15, which is based on debtors' average monthly income during the six months prior to filing.

$X_{y}$ : income exemption per year. This is given on Form B22C, line 16 or line 57, depending on whether debtors have below-median income or not. For debtors with below-median income, the exemption equals the median income level in Delaware, adjusted for family size. For debtors with above-median income, it equals the sum of the rent, transport, personal care, and other allowances, as described in the text.

$M_{1}^{\prime}$ : mortgage and other payment during the repayment plan. We use two sources of data to construct this variable: the debtor's monthly payment under the Chapter 13 plan (taken from the plan filing) and the debtor's normal monthly mortgage payment (taken from Schedule J, questions Q1, Q3, and Q13). Payments under the plan include the cost of repaying mortgage arrears and interest on arrears, but normally do not include regular mortgage payments. The debtor's normal monthly mortgage payment includes first and second mortgage payments, property taxes, insurance, and maintenance cost.

We add the two monthly payments and convert them to present value using a discount rate of $3 \%$ per year. This gives us a multiplier of 56 that converts monthly payments to present value, assuming a 5-year plan. Since we have data on the length of the repayment plan, we adjust the calculation if the plan is less than 5 years.

\section{$M_{2}^{\prime}$ : normal mortgage payment from the end of the repayment plan to the end of the}

mortgage. We start with data on the monthly normal mortgage payment (taken from Schedule J, questions Q1, Q3, and Q13). Since we don't know the remaining term of the mortgage, we 
assume that it is 28 years from the date of filing. We convert the monthly normal mortgage payment to present value using a 3\% discount rate. Then we add the payments from years 6 through 28 to get the present value of mortgage payments from the end of the repayment plan through the end of the mortgage. This gives us a multiplier of 165 that converts normal monthly payments to present value, assuming a 5-year plan. If the repayment plan is less than five years, then we adjust the multiplier.

$M^{\prime}$ : total mortgage payments during and after the repayment plan. This equals $M_{1}^{\prime}+M_{2}^{\prime}$.

$A^{\prime}$ : automobile loans and priority debt: Debt figures are taken from the Summary of Schedules. We add automobile loans and priority debt, since both are paid before unsecured debt and both therefore increase the mortgage subsidy. These debts must be repaid in full during the repayment plan. Debt is converted to present value without discounting, which means that the interest rate is assumed to be the same as the discount rate.

$P^{\prime}$ : unsecured debt. The principle amount of unsecured debt equals the sum of credit card debt, bank debt, medical bills and student loans. Figures are taken from the Summary of Schedules. We assume that whatever unsecured debt is repaid will be paid in full during the repayment plan. Because the debt is unsecured, there is no interest during the plan. Future payments are discounted at the rate of $3 \%$, giving a multiplier of 0.92 that converts dollars of debt to present value of future payments.

$X_{v}$ : homestead exemption. $\$ 50,000$ in Delaware.

$C_{b}$ : bankruptcy cost. This is the sum of debtors' lawyers' fees paid at the time of filing plus the Chapter 13 filing fee of $\$ 274$. We take the lawyer's fee from the "Statement of Compensation of Attorney for Debtor" or from the repayment plan, front page. Where this figure is missing, we substitute the average value. Trustees' fees and lawyers' fees not paid at filing are included in $M_{1}^{\prime}$; see the discussion above.

$R^{\prime}$ : alternate housing cost. We assume that the cost of renting alternate housing equals $25 \%$ of debtors' income. Rent is assumed to increase at a rate of $2 \%$ per year and is discounted to present value at a rate of $3 \%$ per year. The resulting multiplier per dollar of annual rent is 18.9. Renters are also assumed to incur a one-time moving cost in the first year of $\$ 2,000$. Data on the distribution of rent payments to income in Delaware is taken from U.S. Census Bureau (2004), table 958. 
$C_{f}$ : cost of foreclosure. Based on Pence (2003), we assume that the cost of foreclosure equals $30 \%$ of house value.

M: original mortgage principle. Taken from Schedule D. 


\section{Theoretical Appendix}

This appendix gives derivations of the boundaries of the four default/bankruptcy regions shown in figure 1. Debtors' decisions to default on the mortgage and file for bankruptcy are considered separately for five ranges of housing values, starting from the lowest.

Case (i): $V<M_{2}^{\prime}-R^{\prime}$. Here, the value of the debtors' homes in period 1 is so low that the cost of alternate rental housing in present value terms, $R^{\prime}$, is less than the cost of owning $M_{2}^{\prime}-V$, even if debtors make no mortgage payments during the repayment period.

First consider debtors' bankruptcy decision when their incomes are below the state median income level. Because all of their income is exempt in bankruptcy, they receive no mortgage subsidy. They therefore prefer to default on the mortgage, regardless of whether they

file for bankruptcy. Now consider their bankruptcy decisions. If they file under Chapter 13, the present discounted value of their net wealth is $N Y+V_{a}-A^{\prime}-C_{b}-R^{\prime}$; while if they do not file, it is $N Y+V_{a}-A^{\prime}-P^{\prime}-R^{\prime} . V_{a}$ denotes the value of debtors' cars. Because $P^{\prime}>C_{b}$, they prefer bankruptcy.

Now consider debtors' bankruptcy decision when their incomes are above the state median income level. If they file for bankruptcy, they receive the mortgage subsidy, which reduces the cost of owning from $M^{\prime}-V$ to as low as $M_{2}^{\prime}-V$. However even with this subsidy, they are better off defaulting on the mortgage because the cost of renting is lower than the cost of owning, i.e., $R^{\prime}<M_{2}^{\prime}-V$. They therefore choose between default/bankruptcy and default/no bankruptcy. The present discounted value of their net wealth if they choose the former is $(N-5) Y+\left[5 X_{y}+A^{\prime}\right]+V_{a}-A^{\prime}-C_{b}-R^{\prime}$; while if they choose the latter it is $N Y+V_{a}-A^{\prime}-P^{\prime}-R^{\prime} . Y_{1}^{B}$ denotes the income level where debtors in case (i) are indifferent between filing versus not filing for bankruptcy or, $5 Y_{1}^{B}-\left(5 X_{y}+A^{\prime}\right)-C_{b}=P^{\prime}$ Here, debtors' gain from having their unsecured debt discharged in bankruptcy $P^{\prime}$ is just offset by the present 
value of their disposable income plus bankruptcy costs, $5 Y_{1}^{B}-\left(5 X_{y}+A^{\prime}\right)+C_{b}$, or their costs of filing. Debtors file if their income is below $Y_{1}^{B}$, but not otherwise. ${ }^{43}$

Figure 1 shows debtors' period 1 income $Y$ on the horizontal axis and their period 1 housing value $V$ on the vertical axis. Case (i) is the lowest horizontal band. Debtors always default on their mortgages, but they file for bankruptcy if income is below $Y_{1}^{B}$ and do not file otherwise.

Case (ii): $\quad M_{2}^{\prime}-R^{\prime}<V<M^{\prime}-R^{\prime}$. Here, housing value is higher, but the cost of rental housing $R^{\prime}$ is still less than the cost of owning, $M^{\prime}-V$. In this range of values, the mortgage subsidy in Chapter 13 causes some debtors to change from defaulting on their mortgages to saving their homes.

Debtors whose incomes are below the income exemption face the same choice as those in case (i) and they still default and file for bankruptcy. However those whose incomes are above the exemption receive the mortgage subsidy if they keep their homes in bankruptcy and, in this case, their income during the repayment period becomes $\min \left[5 Y, 5 X_{y}+A^{\prime}+M_{1}^{\prime}\right]$. Consider debtors' choice whether to default. The discounted present value of their wealth if they choose default/bankruptcy is $\left((N-5) Y+\min \left[5 Y, 5 X_{y}+A^{\prime}\right]+V_{a}-A^{\prime}-R^{\prime}-C_{b}\right.$; while if they choose no default/bankruptcy it is $(N-5) Y+\min \left[5 Y, 5 X_{y}+A^{\prime}+M_{1}^{\prime}\right]+V_{a}-A^{\prime}+V-M^{\prime}-C_{b}$. When income during the repayment period is $5 X_{y}+A^{\prime}$ or less, they prefer to default, and when it is $5 X_{y}+\left(M_{1}^{\prime}+A^{\prime}\right)$ or more, they prefer to keep their homes. The income level $Y_{2}^{B}$ where case (2) debtors are indifferent between defaulting and not defaulting satisfies the condition $5 Y_{i i}^{B}-\left[5 X_{y}+A^{\prime}\right]=M^{\prime}-V-R^{\prime}$. Here the extra cost to debtors of keeping their houses rather than defaulting (the right-hand side) just equals the amount of income they must use to repay unsecured debt in bankruptcy (the left-hand side). Debtors default if their income is less than $Y_{i i}^{B}$ and they keep their homes otherwise.

Debtors may also be forced to default because they are liquidity-constrained, even when it is financially advantageous for them to keep their homes. The first year's cost of the repayment

${ }^{43}$ This applied if $5 Y>5 X_{y}+A^{\prime}$. But the result remains the same if $5 X_{y}<5 Y<5 X_{y}+A^{\prime}$. 
plan is $C_{b}+\left(M_{1}^{\prime}+A^{\prime}\right) / 5$ and we make the assumption that debtors are willing to use half of their income to repay the mortgage if it is financially worthwhile to do so. Debtors in case (ii) thus default if either they are liquidity-constrained or if their incomes are below the condition discussed above, so that $5 Y_{i i}^{D}=\max \left[5 X_{y}+A^{\prime}+M-V-R, 5 C_{b}+M_{1}^{\prime}+A^{\prime}\right]$.

Now consider debtors' bankruptcy decision when their incomes exceed the income exemption, or $5 Y>5 X_{y}+A^{\prime}+M_{1}^{\prime}$. At a sufficiently high income level, debtors prefer not to file for bankruptcy. But if they do not file, they receive no mortgage subsidy and this means that they prefer to default rather than keep their homes. Therefore high-income debtors choose between the alternatives of default/no-bankruptcy and no-default/bankruptcy. The discounted present value of their wealth in the former situation is $N Y+V_{a}-A^{\prime}-P^{\prime}-R^{\prime}$; while in the latter it is $(N-5) Y+\left[5 X_{y}+M_{1}^{\prime}+A^{\prime}\right]+V_{a}-A^{\prime}+V-M^{\prime}-C_{b}$. Debtors are indifferent between these alternatives at the income level $Y_{2}^{B}$ that satisfies the condition $5 Y_{2}^{B}-\left[5 X_{y}+M_{1}^{\prime}+A^{\prime}\right]+\left(M^{\prime}-V\right)-R^{\prime}+C_{b}=P^{\prime}$. Here, their net gain from debt discharge in bankruptcy (the right-hand side) is just offset by the cost of giving up their non-exempt income during the repayment period plus the extra cost of keeping their homes rather than renting (the left-hand side) plus the cost of filing. They choose no-default/bankruptcy if their incomes are below $Y<Y_{i i}^{B}$ and they choose default/no-bankruptcy otherwise. Note that $Y_{i i}^{B}$ increases as $V$ rises, because debtors gain more from keeping their homes when home value is higher and this induces them to file for bankruptcy at higher income levels.

Assuming that $Y_{i i}^{D}<Y_{i i}^{B}$, debtors in case (ii) default and file for bankruptcy in the lowest income range, default but avoid bankruptcy in the highest income range, and save their homes in bankruptcy in the middle income range. However for some debtors, there is no middle income range where their save their homes (i.e., $Y_{i i}^{B} \geq Y_{i i}^{D}$ ). This is because they have little unsecured debt, so that the mortgage subsidy is too small to change their default decisions.

The second-lowest horizontal bar in Figure 1 shows the results in case (ii) when the middle sub-region exists. 
Case (iii). $M^{\prime}-R^{\prime}<V<M^{\prime}+X_{h}+C_{f}$. In case (iii), the cost of owned housing $M^{\prime}-V$ is less than the cost of rental housing $R^{\prime}$ and debtors therefore prefer to keep their homes. Their homes are not valuable enough to force them to repay any unsecured debt in bankruptcy.

Consider debtors whose incomes are below the state median level first. While they prefer to keep their homes, they may be liquidity-constrained. We assume that debtors are liquidityconstrained if $5 Y_{i i i}^{D}<5 C_{b}+\left(M_{1}^{\prime}+A^{\prime}\right)$. Debtors who default because they are liquidityconstrained also file for bankruptcy, since $P^{\prime}>C_{b} \cdot{ }^{44}$

Next consider debtors' decisions if they are not liquidity-constrained but have incomes below the income exemption. They still prefer to file for bankruptcy, so consider whether they default. The present value of their wealth if they choose default/bankruptcy is $N Y+V_{a}-A^{\prime}-R^{\prime}-C_{b}$; while the present value of their wealth if they choose nodefault/bankruptcy is $N Y+V_{a}-A^{\prime}+V-M^{\prime}-C_{b}$. They prefer not to default since $V>M^{\prime}-R^{\prime}$.

Finally consider debtors' bankruptcy decisions when their incomes exceed the income exemption including the mortgage subsidy. Since they do not default, the present value of their wealth if they choose no-default/bankruptcy is $(N-5) Y+\left[5 X_{y}+M_{1}^{\prime}+A^{\prime}\right]+V_{a}-A^{\prime}+V-M^{\prime}-C_{b}$; while the present value of their wealth if they choose no-default/no-bankruptcy is $N Y+V_{a}-A^{\prime}+V-M^{\prime}-P^{\prime}$. They are indifferent between the two choices at the income level $5 Y_{i i i}^{B}=5 X_{y}+M_{1}^{\prime}+A^{\prime}+P^{\prime}-C_{b}$.

Figure 1 shows the results for case (iii) in the middle horizontal band. Debtors default because they are liquidity-constrained and file for bankruptcy in the lowest income region and they do neither in the highest income region. In-between, they receive the mortgage subsidy and save their homes, but they would have kept their homes anyway. Compared to case (ii), fewer debtors default but more file for bankruptcy.

\footnotetext{
${ }^{44}$ These debtors may file under Chapter 7 if they have already given up their homes. Or they might file under Chapter 13, but give up their homes when they realize that they cannot afford a repayment plan.
} 
Case (iv). $\quad M^{\prime}+X_{h}+C_{f}<V \leq M^{\prime}+X_{h}+C_{f}+P^{\prime}-C_{b}$. Here home equity $V-M^{\prime}$ exceeds the cost of foreclosure plus the homestead exemption. Therefore in a foreclosure, the house would sell for enough to pay $V-M^{\prime}-X_{h}-C_{f}>0$ to unsecured creditors. Case (iv) is unlikely to occur in states with high homestead exemptions, but may occur in states with low homestead exemptions. We abbreviate $V-M^{\prime}-X_{h}-C_{f}$ as $N E H E$, for “non-exempt home equity."

Consider debtors whose incomes are below the income exemption. Even though they have no disposable income, the "best interests of creditors" test requires that they repay unsecured creditors NEHE. And because they have no wealth other than their home equity, they must pay this amount from income even though their incomes would otherwise be exempt. Debtors are assumed to be liquidity-constrained if the first year's cost of the repayment plan exceeds half of their incomes. The maximum income level at which debtors default because they are liquidity constrained is $5 Y_{i v}^{D}=5 C_{b}+\left(M_{1}^{\prime}+A^{\prime}+N E H E\right)$. Liquidity-constrained debtors also file for bankruptcy.

Now consider debtors who are not liquidity-constrained. They do not default, so consider their bankruptcy decisions. Their wealth if they do not file is $N Y+V_{a}-A^{\prime}+V-M^{\prime}-P^{\prime}$. Their wealth if they file is $(N-5) Y+\min \left[5 Y, 5 X_{y}+A^{\prime}+M_{1}^{\prime}\right]+V_{a}-A^{\prime}+V-M^{\prime}-N E H E-C_{b}$, depending on whether their incomes are below or above the income exemption. In the former case, debtors prefer to file for bankruptcy as long as unsecured debt exceeds $C_{b}+N E H E$. In the latter case, debtors are indifferent between filing and not filing at an income level $5 Y_{i v}^{B}=5 Y_{i i i}^{B}-N E H E$. They file if their incomes are below $Y_{4}^{B}$ and not otherwise.

Figure 1 shows debtors' choices in case (iv) as the second-highest horizontal band. Debtors in case (iv) are more likely to be liquidity-constrained than those in case (iii), because case (iv) debtors must repay some of their unsecured debt in addition to repaying their mortgages. Debtors in case (iv) are less likely to file for bankruptcy as the value of their homes rises, because they must repay more to unsecured creditors in bankruptcy.

Case (v). $V>M^{\prime}+X_{h}+C_{f}+P^{\prime}-C_{b}$. In case (v), the value of the house is so high that selling it would generate enough to repay unsecured creditors in full. This means that debtors in case (v) never file for bankruptcy. They also never default on their mortgages. If they are liquidity- 
constrained, they prefer to sell their homes outside of bankruptcy and repay both the mortgage and their unsecured debt in full. The top horizontal bar in figure 1 shows the results in case (v). 
Table 1: Summary Statistics for All Chapter 13 Filers and for Repayment Plans

\begin{tabular}{|c|c|c|}
\hline & Mean & Std. deviation \\
\hline If homeowner & .96 & .20 \\
\hline If debtor passes the means test & .77 & .42 \\
\hline Income & $\$ 39,900$ & $\$ 23,400$ \\
\hline House value (if positive) & $\$ 197,000$ & $\$ 122,000$ \\
\hline If home equity positive (for homeowners) & .71 & .46 \\
\hline Home equity (for all homeowners) & $\$ 39,800$ & $\$ 70,000$ \\
\hline If mortgage listed at filing & .83 & .38 \\
\hline Mortgage principle (if positive) & $\$ 154,000$ & $\$ 109,000$ \\
\hline If auto loan listed at filing & .57 & .50 \\
\hline Auto loan (if positive) & $\$ 18,400$ & $\$ 17,300$ \\
\hline If priority debt listed at filing & .52 & .50 \\
\hline Priority debt (if positive) & $\$ 8,500$ & $\$ 18,600$ \\
\hline If unsecured debt listed at filing & .89 & .32 \\
\hline Unsecured debt (if positive) & $\$ 29,800$ & $\$ 37,500$ \\
\hline If student loans listed at filing & .16 & .37 \\
\hline Student loans (if positive) & $\$ 15,000$ & $\$ 23,800$ \\
\hline Lawyers' fee & $\$ 2,800$ & $\$ 940$ \\
\hline If repayment plan & .90 & .30 \\
\hline If mortgage debt in plan (plan filers only) & .79 & .41 \\
\hline If auto debt in plan (plan filers only) & .45 & .50 \\
\hline If priority debt in plan (plan filers only) & .09 & .29 \\
\hline If unsecured debt in plan (plan filers only) & .42 & .49 \\
\hline If student loans in plan (plan filers only) & .006 & .077 \\
\hline If only unsecured debt in plan (plan filers only) & .09 & .29 \\
\hline Trustee’s fee (plan filers only) & $\$ 2,900$ & $\$ 2,500$ \\
\hline
\end{tabular}


Table 2: Summary Statistics for Chapter 13 Filers with Repayment Plans

\begin{tabular}{|l|c|c|}
\hline & Mean & S.D. \\
\hline Income $(Y)$ & $\$ 42,600$ & $\$ 21,900$ \\
\hline Income exemption $\left(X_{y}\right)$ & $\$ 56,500$ & $\$ 17,500$ \\
\hline Homestead exemption $\left(X_{h}\right)$ & $\$ 50,000$ & 0 \\
\hline House value $(V)$ & $\$ 197,000$ & $\$ 119,000$ \\
\hline Home equity & $\$ 45,000$ & $\$ 73,300$ \\
\hline Bankruptcy cost $\left(C_{b}\right)$ & $\$ 2,900$ & $\$ 800$ \\
\hline Mortgage principle $(M)$ & $\$ 150,000$ & $\$ 105,000$ \\
\hline $\begin{array}{l}\text { Present value of future mortgage payments during and after } \\
\text { the repayment plan, including arrears }\left(M^{\prime}\right)\end{array}$ & $\$ 525,000$ & $\$ 132,000$ \\
\hline Present value of future unsecured debt payments $\left(P^{\prime}\right)$ & $\$ 26,500$ & $\$ 35,000$ \\
\hline $\begin{array}{l}\text { Present value of future payments on auto loans, including } \\
\text { payments on priority debt and student loans }\left(A^{\prime}\right)\end{array}$ & $\$ 19,700$ & $\$ 32,200$ \\
\hline $\begin{array}{l}\text { Present value of the cost of alternate rental housing, } \\
\text { including moving costs }\left(R^{\prime}\right)\end{array}$ & $\$ 203,000$ & $\$ 103,000$ \\
\hline
\end{tabular}

Note: See Data Appendix for discussion of how the present value of future loan payments other costs is calculated. 
Table 3: Simulation Results

\begin{tabular}{|c|c|c|c|}
\hline & $\begin{array}{l}\text { Base Case } \\
\text { (1) }\end{array}$ & $\begin{array}{l}\text { 25\% Lower } \\
\text { Housing } \\
\text { Value } \\
\text { (2) }\end{array}$ & $\begin{array}{l}\text { Cramdown } \\
\text { and } 25 \% \\
\text { Lower } \\
\text { Housing } \\
\text { Value } \\
\text { (3) }\end{array}$ \\
\hline \multicolumn{4}{|l|}{ All Chapter 13 filers: } \\
\hline if bankruptcy predicted & .92 & .94 & .94 \\
\hline if default predicted & .57 & .59 & .50 \\
\hline if house value $<$ mortgage & .15 & .56 & .56 \\
\hline \multicolumn{4}{|l|}{$\begin{array}{l}\text { Group I: Filers who default because they are } \\
\text { liquidity-constrained: }\end{array}$} \\
\hline Proportion of Chapter 13 filers & 32 & 18 & 14 \\
\hline Income & $\$ 38,700$ & $\$ 37,600$ & $\$ 34,500$ \\
\hline Unsecured debt & $\$ 26,600$ & $\$ 31,400$ & $\$ 32,000$ \\
\hline Future mortgage payments in present value & $\$ 333,000$ & $\$ 294,000$ & $\$ 270,000$ \\
\hline Home equity & $\$ 54,100$ & $\$ 22,800$ & $\$ 43,400$ \\
\hline Credit card subsidy (if filers received it) & $\$ 2,900$ & $\$ 3,000$ & $\$ 3,000$ \\
\hline Cram-down subsidy (if filers received it) & -- & -- & $\$ 2,900$ \\
\hline \multicolumn{4}{|l|}{$\begin{array}{l}\text { Group II: Filers who save their homes due to } \\
\text { the mortgage subsidy and/or cram-down:* }\end{array}$} \\
\hline Proportion of Chapter 13 filers & .009 & .005 & .102 \\
\hline Income & $\$ 71,400$ & $\$ 93,700$ & $\$ 65,000$ \\
\hline Unsecured debt & $\$ 93,500$ & $\$ 40,300$ & $\$ 35,000$ \\
\hline Future mortgage payments in present value & $\$ 732,000$ & $\$ 742,000$ & $\$ 356,000$ \\
\hline Home equity & $\$ 45,700$ & $-\$ 40,000$ & $-\$ 74,000$ \\
\hline Credit card subsidy & $\$ 44,900$ & $\$ 40,300$ & $\$ 10,000$ \\
\hline
\end{tabular}




\begin{tabular}{|l|c|c|c|}
\hline Cram-down subsidy & -- & -- & $\$ 134,000$ \\
\hline & & & \\
\hline $\begin{array}{l}\text { Group III: Filers who receive the mortgage } \\
\text { subsidy/cramdown, but would have kept their } \\
\text { homes anyway: }\end{array}$ & & & \\
\hline Proportion of all Chapter 13 filers & .37 & .38 & .42 \\
\hline Income & $\$ 48,100$ & $\$ 47,600$ & $\$ 48,300$ \\
\hline Unsecured debt & $\$ 30,300$ & $\$ 30,100$ & $\$ 30,200$ \\
\hline Future mortgage payments in present value & $\$ 257,000$ & $\$ 250,000$ & $\$ 232,000$ \\
\hline Home equity & $\$ 40,000$ & $\$ 1,500$ & $-\$ 3,400$ \\
\hline Credit card subsidy & $\$ 4,500$ & $\$ 4,800$ & $\$ 4,500$ \\
\hline Cram-down subsidy & -- & -- & $\$ 31,600$ \\
\hline
\end{tabular}

Notes: All figures except proportions are average values.

*Group II includes only debtors in the lower part of the ND/B region if there is no cramdown (columns (1) and (2)). If cram-down is in effect (column (3)), group II also includes debtors who were liquidity-constrained before cram-down, but save their homes once cram-down is introduced. 
Figure 1: Homeowners' Predicted Bankruptcy and Default Decisions

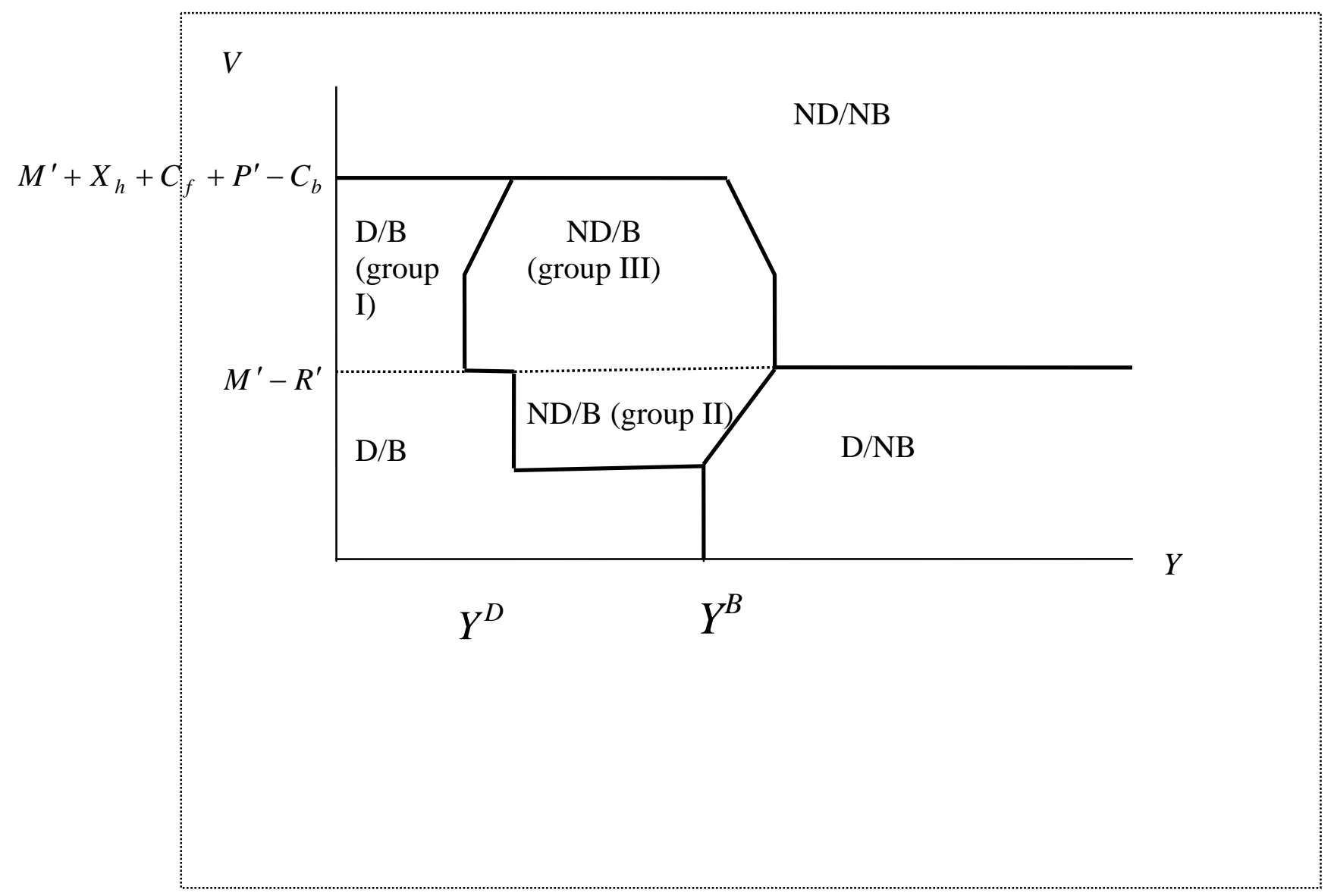

Notes: D indicates default on the mortgage, ND indicates no default, B indicates that debtors file for bankruptcy, and NB indicates no bankruptcy. $Y$ denotes debtors' income and $V$ denotes home value. Other notation is described in the text. 